\title{
Intraoral Mucoepidermoid Carcinoma of Salivary Glands: Lack of Association Among Clinicopathological Features and Immunoexpression of c-erbB-2 in 29 Cases
}

\author{
Carcinoma Mucoepidermoide de Glándulas Salivales Intraoral: \\ Factores Clínicos y Patológicos e Inmunoexpresión de c-erbB-2 en 29 Casos \\ Vanessa Fátima Bernardes; Maria Letícia Ramos-Jorge; Maria Auxiliadora Vieira Carmo; \\ Sérgio Vitorino Cardoso; Ricardo Alves Mesquita \& Maria Cássia Ferreira Aguiar
}

BERNARDES, V. F.; RAMOS-JORGE, M. L.; CARMO, M. A. V.; CARDOSO, S. V.; MESQUITA, R. A. \& AGUIAR, M. C. F. Intraoral mucoepidermoid carcinoma of salivary glands: lack of association among clinicopathological features and immunoexpression of c-erbB-2 in 29 cases. Int. J. Morphol., 26(4):1005-1011, 2008.

SUMMARY: The association among clinicopathological features and c-erbB-2 oncoprotein expression was evaluated in twentynine cases of intra-oral mucoepidermoid carcinoma (MEC). MEC was prevalent in the female gender (79.3\%), tumors were more frequent in ages between 21 and 40 years (48.3\%), and the palate was the most commonly affected site (72.4\%). Microscopically, 27 cases $(93.1 \%)$ were classified as low grade of malignancy. The c-erbB-2 expression was considered positive in 9 (31\%) cases and no significant association ( $\mathrm{p}>0.05$ ) was found among protein expression and gender nor between patient age and site or histological grade of the lesion. c-erbB-2 expression in MEC may reflect intrisinc biologic properties of salivary gland neoplasms and may be linked to histogenesis and cellular differentiaton.

KEY WORDS: c-erbB-2; Her-2/neu; Immunohistochemistry; Mucoepidermoid carcinoma; Salivary gland neoplasms.

\section{INTRODUCTION}

The c-erbB-2 proto-oncogene, also known as Her-2/ neu, is located on chromosome 17 and encodes a cell-surface transmembrane glycoprotein known as p185neu. Its intracellular component has a tyrosine kinase activity, whereas the extracellular domain may act as a growth factor receptor because of its considerable homology with epidermal growth factor receptor (Nguyen et al., 2003). The c-erbB-2 oncoprotein is involved in matrix degradation and proteolitic activity as well as in the increase in vessel permeability, endothelial cell growth, proliferation, migration, and differentiation (Verbeek et al., 2003; Sanderson et al., 2006) inducing and mantaining oncogenesis in a great number of human malignancies.

The amplification and/or overexpressiom of c-erbB2 in human tumor tissue has been associated with a poor prognosis in ovarian, endometrial and breast carcinoma (Weed et al., 2004). Previous studies of c-erbB-2 expression in salivary gland carcinomas are sparse, comprise heterogeneous subtypes, and show contradictory results (Locati et al., 2005).
Mucoepidermoid carcinoma (MEC) is the most common malignant neoplasm of major and minor salivary glands (Lopes et al., 2006). MEC is reported to manifest variable biologic aggressiveness, basically showing correlation with its histological features and is graded by a 3-tiered system (Auclair et al., 1992).

Conflicting results have been reported with regard to c-erbB-2 overexpression in mucoepidermoid carcinoma, with reported rates ranging from absent to 38\% (Sugano et al., 1992; Press et al., 1994; Suzuki et al., 1998). Different conclusions may be attributed to the varying techniques used, criteria applied to determine positive c-erbB-2 expression, the diversity of lesions and the limited number evaluated in some studies.

Few papers evaluating only one type of oral salivary gland tumors are available. Thus, the aim of this study was to analyze a series of intraoral MEC for expression of the cerbB-2 oncoprotein and its possible association with the clinicopathologic features of the sample. 
BERNARDES, V. F.; RAMOS-JORGE, M. L.; CARMO, M. A. V.; CARDOSO, S. V.; MESQUITA, R. A. \& AGUIAR, M. C. F. Intraoral mucoepidermoid carcinoma of salivary glands: lack of association among clinicopathological features and immunoexpression of c-erbB-2 in 29 cases. Int. J. Morphol., 26(4):1005-1011, 2008.

\section{MATERIAL AND METHOD}

The protocol of this study was approved by the Committee of Bioethics in Research at the Universidade Federal de Minas Gerais, UFMG (COEP-UFMG 345/05).

Patients. From 1953 to 2006 forty cases were diagnosed as MEC from the files of the Oral Pathology Department, School of Dentistry, Universidade Federal de Minas Gerais. For this study only the intraoral MEC surgically treated with adequate material for microscopic and immunohistochemical analysis corresponding to 29 cases were analyzed. Sinonasal and maxillary tumors were not included in the sample. Clinical information about age, gender, and site were obtained from the biopsy records.

Histopathology. Histopathological diagnosis was revised in new hematoxylin-eosin-stained sections and tumors were graded as low, intermediate, or high according to the histologic grading method of Auclair et al.

Table I. Clinicopathological features of mucoepidermoid carcinoma of salivary glands

\begin{tabular}{|c|c|c|c|c|c|}
\hline Case & $\begin{array}{c}\text { Age } \\
\text { (years) }\end{array}$ & Gender $^{\mathrm{a}}$ & Site & $\begin{array}{c}\text { Malignancy } \\
\text { grade }\end{array}$ & $\begin{array}{c}\text { c-erbB-2/neu } \\
\text { expression }\end{array}$ \\
\hline 1 & 34 & $\mathrm{~F}$ & Retromolar area & Low & Negative \\
\hline 2 & 23 & $\mathrm{~F}$ & Buccal mucosa & Low & Negative \\
\hline 3 & 31 & $\mathrm{~F}$ & Floor of the mouth & Low & Positive $(2+)$ \\
\hline 4 & 35 & $\mathrm{~F}$ & Palate & Intermediate & Negative \\
\hline 5 & 20 & M & Palate & Low & Positive $(2+)$ \\
\hline 6 & 35 & $\mathrm{~F}$ & Palate & Low & Positive (2+) \\
\hline 7 & 53 & M & Palate & Low & Positive $(2+)$ \\
\hline 8 & 66 & $\mathrm{~F}$ & Palate & Low & Negative \\
\hline 9 & 26 & $\mathrm{~F}$ & Palate & Low & Negative \\
\hline 10 & 60 & M & Palate & Low & Positive $(2+)$ \\
\hline 11 & 25 & $\mathrm{~F}$ & Palate & Intermediate & Positive $(2+)$ \\
\hline 12 & 53 & $\mathrm{~F}$ & Palate & Low & Negative \\
\hline 13 & 14 & M & Palate & Low & Negative \\
\hline 14 & 40 & $\mathrm{~F}$ & Palate & Low & Negative \\
\hline 15 & 55 & $\mathrm{~F}$ & Palate & Low & Negative \\
\hline 16 & 65 & M & Retromolar area & Low & Negative \\
\hline 17 & 41 & $\mathrm{~F}$ & Palate & Low & Positive (3+) \\
\hline 18 & 64 & $\mathrm{~F}$ & Floor of the mouth & Low & Negative \\
\hline 19 & 73 & $\mathrm{~F}$ & Palate & Low & Negative \\
\hline 20 & 14 & $\mathrm{~F}$ & Palate & Low & Negative \\
\hline 21 & 43 & $\mathrm{~F}$ & Palate & Low & Negative \\
\hline 22 & 32 & $\mathrm{~F}$ & Palate & Low & Negative \\
\hline 23 & 16 & $\mathrm{~F}$ & Palate & Low & Negative \\
\hline 24 & 21 & $\mathrm{~F}$ & Retromolar area & Low & Positive $(2+)$ \\
\hline 25 & 48 & $\mathrm{~F}$ & Retromolar area & Low & Negative \\
\hline 26 & 55 & M & Palate & Low & Negative \\
\hline 27 & 23 & $\mathrm{~F}$ & Buccal mucosa & Low & Positive $(2+)$ \\
\hline 28 & 36 & $\mathrm{~F}$ & Palate & Low & Negative \\
\hline 29 & 28 & $\mathrm{~F}$ & Palate & Low & Negative \\
\hline
\end{tabular}

aF: feminine / M: masculine 
BERNARDES, V. F.; RAMOS-JORGE, M. L.; CARMO, M. A. V.; CARDOSO, S. V.; MESQUITA, R. A. \& AGUIAR, M. C. F. Intraoral mucoepidermoid carcinoma of salivary glands: lack of association among clinicopathological features and immunoexpression of c-erbB-2 in 29 cases. Int. J. Morphol., 26(4):1005-1011, 2008.

Immunohistochemistry (IHC). IHC was performed with a standard, monoclonal antibody CB11 (Novocastra Laboratories, Newcastle Upon Tyne, UK). Briefly, $4 \mu \mathrm{m}$ sections were dewaxed in xylene and hydrated with graded ethanol. Blocking of endogenous peroxidase and avidinbiotin activity were performed (Miller et al., 1999). The slides were placed in a $10 \mathrm{mM}$ ethylenediaminetetraacetic acid (EDTA) buffer, $\mathrm{pH}$ 8.0 , heated to $96{ }^{\circ} \mathrm{C}$ in a steamer for 25 minutes, incubated with the primary antibody for $18 \mathrm{~h}$ at room temperature, and diluted 1:200 in a 1\% bovine serum albumin (BSA). After washing in the Tris$\mathrm{HCl}$ buffer, sections were incubated for $30 \mathrm{~min}$ at room temperature with biotinylated multi-link swine anti-goat, mouse, and rabbit immunoglobulin (LSAB kit, Dako, Carpinteria, CA, USA). The reactions were revealed by applying $0.01 \%$ diaminobenzidine tetrahydrochloride (DAB) (Sigma-Aldrich, St. Louis, MO, USA) and 0.03\% $\mathrm{H}_{2} \mathrm{O}_{2}$. The sections were counterstained with Mayer's haematoxylin and mounted in Permount (Fisher Scientific, NJ, USA). In situ intraductal carcinoma of the breast was used as a c-erbB-2 positive control and negative controls were obtained by the omission of the primary antibody.

Evaluation of the immunohistochemical staining. Tumors were scored on a 0-3+ scale, as follows: 0 , staining in $<10 \%$ of tumor cells or no staining; $1+$, faint and partial membrane staining in $\geq 10 \%$ of tumor cells; $2+$, weak to moderate complete membrane staining in $\geq 10 \%$ of tumor cells; or $3+$, moderate to strong complete membrane staining in $\geq 10 \%$ of tumor cells. Scores of either $2+$ or $3+$ were defined as c-erbB2 overexpression. The slides were independently evaluated by two observers (VFB, MCFA) with neither prior discussion nor knowledge about the clinical features and malignancy grade. Discrepancies were solved by consensus.

Statistical analysis. Significance was evaluated by the Chi-square test using the SPSS program with a $p<0.05$ significance level (SPSS, 2003).

\section{RESULTS}

From 22688 oral biopsies submitted during period between 1953 and 2006, $40(0.18 \%)$ MEC were diagnosed being 29 located in minor salivary glands. Tumors were more common in the third and fourth decades of life $(48.3 \%)$, with predilection for females $(79.3 \%)$. The palate was the most commonly affected site, with 21 cases $(72.4 \%)$. Other intraoral sites included the retromolar area (4), the buccal mucosa (2), and the floor of the mouth (2). The majority of MECs (27 cases) were classified as low grade of malignancy.

c-erbB-2 positive staining of cell surface membranes $(2+$ or $3+$ ) was identified in 9 cases (31\%) of our series. All positive cases also expressed cytoplasmic staining. Both patterns (cell surface membrane/cytoplasmic staining) were observed in mucous, intermediate and epidermoid cells (Figure 1A). Neither staining was observed in adjacent normal salivary gland nor in the stroma. No significant association $(\mathrm{p}>0.05)$ was found among protein expression and gender nor between patient age and site or histological grade of the lesion.


Fig.1. Membranous (arrows) and cytoplasmic (arrowheads) immunoexpression of c-erbB-2 in MEC of mucous, intermediate and epidermoid cells (100x). 
BERNARDES, V. F.; RAMOS-JORGE, M. L.; CARMO, M. A. V.; CARDOSO, S. V.; MESQUITA, R. A. \& AGUIAR, M. C. F. Intraoral mucoepidermoid carcinoma of salivary glands: lack of association among clinicopathological features and immunoexpression of c-erbB-2 in 29 cases. Int. J. Morphol., 26(4):1005-1011, 2008.

\section{DISCUSSION}

MEC is the most common malignancy of salivary glands and presents a diverse age distribution (Auclair $e t$ $a l$.; Lopes et al.). However, there are few articles with a significative number of cases (Lopes et al.). In our series, patients demonstrated an earlier average age of occurrence, with a peak of incidence in the third and fourth decades of life, whereas previous studies described a prevalence in fifth and sixth decades of life (Auclair et al.; Lopes et al.). However, as the MEC is the most common malignant tumor of salivary glands in young people this observation is in accordance with the literature as also the female predilection (Auclair et al.; Triantafillidou et al., 2006).

Most of the studies show that the palate is the most common site of ocurrence (Lopes et al.; Kokemueller et al., 2005). In our series the results were similar with 21 $(72.4 \%)$ cases affecting the hard palate. Sinonasal and maxillary tumors were not included in this study as intraoral salivary gland tumors since that in these locations mucoepidermoid carcinoma presents different origin rather than glandular (Ellis et al., 1991).

Microscopically, most intraoral MEC were classified as low grade of maligancy (27cases - 93.1\%), followed by intermediate $(2-6,9 \%)$ and no case of highgrade as expected. Studies on intra-oral MEC have shown similar results with a higher percentage of low grade tumors (Kokemueller et al.; Lopes et al). Low grade tumors seem to arise more often in minor salivary glands, which according to some authors are detected at earlier stages, probably due to the less aggressive growth in addition to a better visible tumor site. High grade tumors, on the other hand, seem to arise more often in major salivary glands (Kokemueller et al.).

Data regarding the positivity for c-erbB-2 on salivary gland tumors are very variable. Kärjä et al. (1994) described positivity in $44 \%$ of cases, including malignant and benign tumors. However, other studies reported a rare expression of c-erbB-2 on these tumors (Kernohan et al., 1991; Shrestha et al., 1992).

Concerning MEC, there had been only individual case descriptions of c-erbB-2 expression (Kernohan et al.; Shrestha et al.) before a study of Press et al. These authors observed the gene amplification and protein overexpression of c-erbB-2 in 21\% and 38\% of MEC respectively. Cho et al. (1997) showed a similar prevalence. However, some authors described a far greater rate, with almost $80 \%$ of the MEC positive for c-erbB-2 in their series, although the criteria for analysis of positivity was not presented (da Cruz Perez et al., 2004; Lopes et al.). We observed c-erbB-2 membranous expression in $9(31 \%)$ of cases in our series which is in accordance with previous report (Press et al.).

We suppose that reasons for this contradictory results are associated with the immunohistochemistry technique, in special with the primary antibody employed and with the subjective interpretation and semiquantitative nature of the results. There is no consensus about the best antibody for the evaluation of c-erbB-2 immunoexpression (Hanna et al., 2001). The CB11 antibody used here has shown the best concordance with FISH (fluorescent in situ hybridization) technique (Gouvea et al., 2006). This antibody although less sensitive than the polyclonal antibody used in other reports (Lopes et al.; Gouvea et al.) is considered more specific (Kernohan et al., Handra-Luca et al., 2003; Kamio et al.).

Besides, in the present study a standardized method was employed for evaluation of positivity. The high percentage of previously observed positive cases (21 cases, $77.7 \%$ ) (Lopes et al.) as compared to our series (9 cases, $31 \%$ ) may be due to differences in methods of interpretation.

Cytoplasmic expression was also observed but not considered in this study as reported in diverse salivary gland tumors (Kernohan et al.). Although the significance of this cytoplasmic staining remains unknown, Cheng et al. (2005) suggested that this pattern reflects degenerated c-erbB-2 fragments with less functional ability. Further studies in order to clarify this point are warranted.

There have been suggestions that the overexpression of c-erbB-2 on salivary gland tumors is related with histogenesis of these lesions (Glisson et al., 2004; Rivière et al., 1991; Gibbons et al., 2001, Rosa et al., 1997). MEC is composed of varying proportions of mucous, epidermoid, columnar, intermediate and clear cells (Auclair et al.) and is though to arise from the salivary excretory duct (Ellis $e t$ $a l$.). Glisson et al. suggested that c-erbB-2 has a higher frequency of overexpression in tumors derived from excretory duct (e.g. MEC) than that from intercalated duct. For Rivière et al. the expression of c-erbB-2 on salivary gland tumors may reflect accident of genomic reconstitutional events ocurring within the differential pathway of mioepithelial/epithelial cells which justify the overexpression of this oncogene in tumors of intercalated duct origin. 
BERNARDES, V. F.; RAMOS-JORGE, M. L.; CARMO, M. A. V.; CARDOSO, S. V.; MESQUITA, R. A. \& AGUIAR, M. C. F. Intraoral mucoepidermoid carcinoma of salivary glands: lack of association among clinicopathological features and immunoexpression of c-erbB-2 in 29 cases. Int. J. Morphol., 26(4):1005-1011, 2008.

However, many studies found that benign and malignant salivary gland neoplasms with evidence of myoepithelial lineage do not overexpress c-erbB-2 protein which support the view that this growth receptor is not involved in their pathogenesis (Rosa et al., Shrestha et al.; Kamio et al.). In contrast, the c-erbB-2 is expressed by high grade carcinomas as salivary duct carcinoma, high grade carcinoma, and exclusively by the malignant component of carcinoma ex pleomorpic adenoma (Johnson et al., 2008; Nabili et al., 2007; Matsubayashi \& Yoshihara, 2007). Although the latter may present myoepitelial derivation, carcinoma ex pleomorphic adenoma probably adquired a particular biological behavior in the longstanding process of malignant transformation. Moreover, Gibbons et al. demonstrated a clear difference in the molecular phenotypes of MEC and adenoid cystic carcinoma with only MEC overexpressing c-erbB-2. This provides further support to the existence of distinct molecular mechanisms in salivary gland carcinogenesis associated with the overexpression of c-erbB-2.

Despite the small sample studied our results demonstrated no association among c-erbB-2 expression and demographic or histological grades of MEC. Press et $a l$. reported that male gender was significantly associated with neu oncogene amplification and overexpression in MEC. Cho et al. and Nguyen et al. reported that c-erbB-2 expression was more frequent in high grade tumors than in low grade.

The majority of MEC in minor salivary glands are histologically classified as low grade of malignancy and an association with the c-erbB-2 immunopositivity could be not demonstrated. However, in the study of Lopes et al. c-erbB-2 positivity was predominantly observed in lowgrade MEC and differently of other studies, negativity for c-erbB-2 correlated with lowest survival rates. Suzuki et $a l$. also demonstrated that the overexpression of c-erbB-2 on MEC of parotid gland was associated to a poor prognosis independently of the histological grade.

Thus, our findings may suggest the lack of association among clinicopathological features and the immunoexpression of c-erbB-2. Moreover, the significance of c-erbB-2 expression in MEC may reflect intrisinc biologic properties of salivary gland neoplasms (Nguyen et al.). A greater number of studies involving large series with specific histologic subtypes are necessary to highlight the role of cerbB-2 in the pathogenesis of salivary gland neoplasms.

\section{CONCLUSION}

Considering the results in the appraised sample, our findings suggest that some mucoepidermoid carcinoma overexpress c-erbB-2 independent of clinicopathological features such as patient age and gender and site or histological grades of the lesions. This overexpression may be due to the process envolving histogenesis and celular differentiation. Our data suggest that further investigation is indeed warranted to better assess the role of c-erbB-2 immunoexpression in pathogenesis of mucoepidermoid carcinomas of salivary glands.

\section{ACKNOWLEDGEMENTS}

Funding was provided by The Research Foundation of the State of Minas Gerais (FAPEMIG) and The National Council for Scientific and Technological Development (CNPq) supported this work. Aguiar, MCF; Carmo, MAV; and Mesquita, RA are research fellows of the CNPq. We thank Mrs. Ignez Candelori, Universidade Federal de Uberlândia, from her technical support.

BERNARDES, V. F.; RAMOS-JORGE, M. L.; CARMO, M. A. V.; CARDOSO, S. V.; MESQUITA, R. A. \& AGUIAR, M. C. F. Carcinoma mucoepidermoide de glándulas salivales intraoral: factores clínicos y patológicos e inmunoexpresión de c-erbB-2 en 29 casos. Int. J. Morphol., 26(4):1005-1011, 2008

RESUMEN: Fueron evaluados 29 casos de carcinoma mucoepidermoide intraoral en sus aspectos clínico-patológicos, además de la expresión de la oncoproteina c-erbB-2. El carcinoma mucoepidermoide fue predominante en las mujeres (79,3\%), siendo más frecuente en individuos entre 21 y 40 años de edad (48,3\%). El paladar fue el sitio más comunmente afectado (72,4\%). Microscópicamente, 27 casos $(93,1 \%)$ fueron clasificados como de baja malignidad. La expresión del c-erbB-2 se consideró positiva en 9 (31\%) casos y no fue observada ninguna asociación significativa $(\mathrm{p}>0,05)$ entre la expresión de la proteína y género, ni entre la edad de los pacientes y el sitio o el grado histológico de la lesión. La expresión de la c-erbB-2 en el carcinoma mucoepidermoide puede mostrar las propiedades biológicas intrísecas de las neoplasias de las glándulas salivales.

PALABRAS CLAVE: c-erbB-2; Her-2/neu; Inmunohistoquímica; Carcinoma mucoepidermoide; Neoplasmas de las glándulas salivales 
BERNARDES, V. F.; RAMOS-JORGE, M. L.; CARMO, M. A. V.; CARDOSO, S. V.; MESQUITA, R. A. \& AGUIAR, M. C. F. Intraoral mucoepidermoid carcinoma of salivary glands: lack of association among clinicopathological features and immunoexpression of c-erbB-2 in 29 cases. Int. J. Morphol., 26(4): 1005-1011, 2008.

\section{REFERENCES}

Auclair, P. L.; Goode, R. K. \& Ellis, G. L. Mucoepidermoid carcinoma of intraoral salivary glands. Evaluation and application of grading criteria in 143 cases. Cancer, 69(8):2021-30, 1992.

Cheng, C. M.; Tsuneyama, K.; Matsui, K.; Takahashi, H.; Ishizawa, S. \& Takano, Y. Cytoplasmic expression of c-erbB2 in non-small cell lung cancers. Virchows Arch., 446(6):596-603, 2005.

Cho, K. J.; Kim, J. Y.; Lee, S. S. \& Oh, K. K. Mucoepidermoid carcinoma of the salivary gland--a clinico-pathologic and immunohistochemical study for c-erbB-2 oncoprotein. J. Korean Med. Sci., 12(6):499504, 1997.

da Cruz Perez, D. E.; Pires, F. R.; Alves, F. A.; Almeida, O. P. \& Kowalski, L.P. Salivary gland tumors in children and adolescents: a clinicopathologic and immunohistochemical study of fifty-three cases. Int. J. Pediatr. Otorhinolaryngol., 68(7):895-902, 2004.

Ellis, G. L.; Auclair, P. L. \& Gnepp, D. R. Surgical Pathology of the salivary glands. v. 25. PhiladelphiaPA, W.B., Saunders, 1991.

Gibbons, M. D.; Manne, U.; Carroll, W. R.; Peters, G. E.; Weiss, H. L. \& Grizzle, W. E. Molecular differences in mucoepidermoid carcinoma and adenoid cystic carcinoma of the major salivary glands. Laryngoscope, 111(8):1373-8, 2001.

Glisson, B.; Colevas, A. D.; Haddad, R.; Krane, J.; ElNaggar, A.; Kies, M.; Costello, R.; Summey, C.; Arquette, M.; Langer, C.; Amrein, P. C. \& Posner, M. HER2 expression in salivary gland carcinomas: dependence on histological subtype. Clin. Cancer Res., 10(3):944-6, 2004.

Gouvea, A. P.; Milanezi, F.; Olson, S. J.; Leitao, D.; Schmitt, F. C. \& Gobbi, H. Selecting antibodies to detect HER2 overexpression by immunohistochemistry in invasive mammary carcinomas. Appl. Immunohistochem. Mol. Morphol., 14(1):103-8, 2006.

Handra-Luca, A.; Bilal, H.; Bertrand, J. C. \& Fouret, P. Extra-celular signal-regulated ERK-1/ERK-2 pathway activation in human salivary gland mucoepidermoid carcinoma. Am. J. Pathol., 163(3):957-67, 2003.
Hanna, W. M.; Kahn, H. J.; Pienkowska, M.; Blondal, J.; Seth, A. \& Marks, A. Defining a test for HER-2/neu evaluation in breast cancer in the diagnostic setting. Mod. Pathol., 14(7):677-85, 2001.

Johnson, C. J.; Barry, M. B.; Vasef, M. A. \& Deyoung, B. R. Her-2/neu expression in salivary duct carcinoma: an immunohistochemical and chromogenic in situ hybridization study. Appl. Immunohistochem. Mol. Morphol., 16(1):54-8, 2008.

Kamio, N. Coexpression of p53 and c-erbB-2 proteins is associated with histological type, tumour stage, and cell proliferation in malignant salivary gland tumours. Virchows Arch., 428(2):75-83, 1996.

Kärjä, V.; Syrjänen, S.; Kataja, V.; Syrjänen, K. c-erbB-2 oncogene expression in salivary gland tumours. ORL. J. Otorhinolaryngol. Relat. Spec., 56(4):206-12, 1994.

Kernohan, N. M.; Blessing, K.; King, G.; Corbett, I. P. \& Miller, I. D. Expression of c-erbB-2 oncoprotein in salivary gland tumours: an immunohistochemical study. J. Pathol., 163(1):77-80, 1991.

Kokemueller, H.; Brueggemann, N.; Swennen, G.; Eckardt, A. Mucoepidermoid carcinoma of the salivary glands clinical review of 42 cases. Oral Oncology, 41(1):3-10, 2005.

Locati, L. D.; Rinaldi, G.; Bossi, P.; Dagrada, G. P.; Quattrone, P.; Cantu, G. \& Licitra, L. Herceptin plus chemotherapy in relapsed and/or metastatic salivary gland cancer. Oral Oncol., 41(1):97-8, 2005.

Lopes, M. A.; da Cruz Perez, D. E.; de Abreu Alves, F.; de Almeida, O. P. \& Kowalski, L.P. Clinicopathologic and immunohistochemical study of intraoral mucoepidermoid carcinoma. Otolaryngol. Head Neck Surg., 134(4):622-6, 2006.

Matsubayashi, S. \& Yoshihara, T. Carcinoma ex pleomorphic adenoma of the salivary gland: an immunohistochemical study. Eur. Arch. Otorhinolaryngol., 264(7):789-95, 2007.

Miller, R. T.; Kubier, P.; Reynolds, B.; Henry, T. \& Turnbow, H. Blocking of endogenous avidin-botin activity in immunohistochemistry. The use of skim milk as an economical and effective substitute for commercial biotin solutions. Appl. Imm. Mol. Morphol., 7(1):63-5, 1999. 
BERNARDES, V. F.; RAMOS-JORGE, M. L.; CARMO, M. A. V.; CARDOSO, S. V.; MESQUITA, R. A. \& AGUIAR, M. C. F. Intraoral mucoepidermoid carcinoma of salivary glands: lack of association among clinicopathological features and immunoexpression of c-erbB-2 in 29 cases. Int. J. Morphol., 26(4): 1005-1011, 2008.

Nabili, V.; Tan, J. W.; Bhuta, S.; Sercarz, J. A. \& Head, C. S. Salivary duct carcinoma: a clinical and histologic review with implications for trastuzumab therapy. Head Neck., 29(10):907-12, 2007.

Nguyen, L. H. P.; Black, M. J.; Hier, M.; Chauvin, P. \& Rochon, L. Her2/neu and Ki-67 as prognostic indicators in mucoepidermoid carcinoma of salivary glands. $J$. Otolaryngol., 32(5):328-31, 2003.

Press, M. F.; Pike, M. C.; Hung. G.; Zhou, J. Y.; Ma, Y.; George, J.; Dietz-Band, J.; James, W.; Slamon, D. J.; Batsakis, J. G. \& El-Naggar, A. K. Amplification and overexpression of HER-2/neu in carcinomas of the salivary gland: correlation with poor prognosis. Cancer Res., 54(21):5675-82, 1994.

Rivière, A.; Becker, J. \& Löning, T. Comparative investigation of c-erbB2/neu expression in head and neck tumors and mammary cancer. Cancer, 67(8):21429, 1991.

Rosa, J. C.; Felix, A.; Fonseca, I. \& Soares, J. Immunoexpression of c-erbB-2 and p53 in benign and malignant salivary neoplasms with myoepithelial differentiation. J. Clin. Pathol., 50(8):661-3, 1997.

Sanderson, M. P.; Dempsey, P. J. \& Dunbar, A. J. Control of ErbB signaling through metalloprotease mediated ectodomain shedding of EGF-like factors. Growth Factors, 24(2):121-36, 2006.

Shrestha, P.; Huang, J. W.; Tsuji, T.; Shinozak, F.; Maeda, K.; Sasaki, K.; Ueno, K.; Yamada, K. \& Mori, M. Rare expression of the c-erbB-2 oncoprotein in salivary gland tumors: an immunohistochemical study. J. Oral Pathol. Med., 21(10):477-80, 1992.

SPSS. Incorporation SPSS for Windows. Statistical Package for the Social Sciences Version 12.0 Chicago: SPSS Inc, 2003.

Sugano, S.; Mukai, K.; Tsuda, H.; Hirohashi, S.; Furuya, S.; Shimosato, Y.; Ebihara, S. \& Takeyama, I. Immunohistochemical study of c-erbB-2 oncoprotein overexpression in human major salivary gland carcinoma: an indicator of aggressiveness. Laryngoscope, 102(8):923-7, 1992.

Suzuki, M.; Ichimya, I.; Matsushita, F. \& Mogi, G. Histological features and prognosis of patients with mucoepidermoid carcinoma of the parotid gland. $J$. Laryngol. Otol., 112(10):944-77, 1998.
Triantafillidou, K.; Dimitrakopoulos, J.; Iordanidis, F. \& Koufogiannis, D. Mucoepidermoid carcinoma of minor salivary glands: a clinical study of 16 cases and review of the literature. Oral Dis., 12(4):364-70, 2006.

Verbeek, B. S.; Adriaansen-Slot, S. S.; Vroom, T. M.; Beckers, T. \& Rijksen, G. Overexpression of EGFR and c-erbB2 causes enhanced cell migration in human breast cancer cells and NIH3T3 fibroblasts. FEBS Lett., 425(1):145-50, 1998.

Weed, D. T.; Gomez-Fernandez, C.; Pacheco, J.; Ruiz, J.; Hamilton-Nelson, K.; Arnold, D. J.; Civantos, F. J.; Zhang, J.; Yasin, M.; Goodwin, J. \& Carraway, K. L. Muc4 and erbb2 expression in major and minor salivary gland mucoepidermoid carcinoma. Head Neck, 26(4): 353-64, 2004.

Correspondence to:

Profa. Dra. Maria Cássia Ferreira de Aguiar.

Faculdade de Odontologia da UFMG

Laboratório de Patologia Experimental 1- Sala 3201

Av. Antônio Carlos, 6627

CEP: $31270-901$

Pampulha

Belo Horizonte, MG

BRASIL

Tel.: (55 31) 34092476

Fax: (55 31) 34092472

Email: cassiafa@ufmg.br

Received: 28-07-2008

Accepted: 17-10-2008 
